Pamiętnik Literacki 2020, 4, s. 69-81

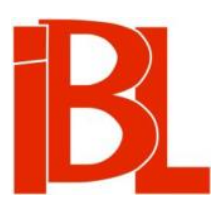

\title{
Pisma Elizy Orzeszkowej - próby krytyczne
}

\author{
Iwona Wiśniewska
}




\section{PISMA ELIZY ORZESZKOWEJ - PRÓBY KRYTYCZNE}

Wbrew obiegowym opiniom Eliza Orzeszkowa nie należy do twórców zapomnianych, przynajmniej - nie przez edytorów i wydawców. Od śmierci pisarki (1910 rok) do dziś pojawiły się trzy zbiorowe wydania jej dorobku - z ambicjami zaprezentowania całości lub przynajmniej większości tego, co powstało pod jej piórem ${ }^{1}$.

Prawie rok po odejściu autorki Nad Niemnem oficyna Gebethnera i Wolffa, w porozumieniu $\mathrm{z}$ właścicielami praw autorskich do jej utworów, postanowiła opublikować Pisma Orzeszkowej ${ }^{2}$. Edycję planowano jako „wydanie zbiorowe zupełne” (tak brzmi podtytuł serii). W roku 1912 ukazało się pierwszych 6 tomów (tom 1 otwierał wstęp Aurelego Drogoszewskiego, krytyka i dobrego, choć głównie korespondencyjnego, znajomego pisarki ${ }^{3}$; jemu też powierzono układ całości i inne decyzje edytorskie), a do r. 1914 - kolejnych 12 . Wybuch pierwszej wojny przerwał prace nad dalszymi pięcioma tomami (woluminy od 19 do 23 nigdy się nie ukazały). W latach dwudziestych XX w. edycje niespodziewanie dopełniono o tomy 24 (1927) i $25(1928)^{4}$.

W roku 1935 przypadała 25 rocznica śmierci pisarki. W tym czasie Towarzystwo imienia Elizy Orzeszkowej postanowiło zainicjować poważne przedsięwzięcie: pierwszą krytyczną edycje jej dzieł. Patronat nad nią objęła Polska Akademia Literatury, wydawca została ponownie oficyna Gebethnera i Wolffa, a przygotowaniem tomów zajęli się przedstawiciele dwóch pokoleń: urodzony w roku powstania styczniowego Aureli Drogoszewski i trzy razy odeń młodszy Ludwik Brunon Świderski (ur. 1913), grodnianin z pochodzenia, świeżo upieczony magister wydziału huma-

1 Nie liczymy tu pomniejszych (kilku- lub kilkunastotomowych) popularnych wyborów twórczości, których w ostatnich 100 latach było sporo.

2 Spadkobiercami praw autorskich do utworów Orzeszkowej (zarówno wydanych, jak i pozostających w rękopisach) byli jej najbliżsi grodzieńscy przyjaciele, Maria i Maksymilian Obrębscy (zob. I. W i śn i e w s k a, Kalendarium życia i twórczości Elizy Orzeszkowej. T. 2: 1897-1910. Warszawa 2014, hasło $\mathrm{nr}$ 4206). Obrębscy zmarli bezdzietnie w czasie pierwszej wojny światowej.

3 A. Drogoszewski prowadził z Orzeszkową obszerną i ciekawą korespondencję w latach 1902-1907 (zob. E. Or zes zk ow a, Listy zebrane. T. 4. Do druku przygot. i koment. opatrzył E. J a n kowski. Wrocław 1958, s. 101-213). Jak przyznał w jednym ze swoich prywatnych listów, osobiście spotkał pisarkę tylko raz (i to przelotnie), wiosną 1909 w Warszawie (zob. A. D rogos zew ski, list do E. Grodzieńskiej, z 28 VI 1938; autograf w Archiwum Elizy Orzeszkowej Instytutu Badań Literackich PAN 〈dalej stosujemy skrót AEO〉, sygn. 1085, k. 31).

4 Zawartość poszczególnych tomów Pism podaje bibliografia Orzeszkowej z Nowego Korbuta (t. 17, vol. 2): H. G a c o w a, Eliza Orzeszkowa. Wrocław-Warszawa-Kraków 1999, poz. 470, s. 83. 
nistycznego Uniwersytetu Warszawskiego, asystent profesora Juliana Krzyżanowskiego w Katedrze Historii Literatury Polskiej UW, sekretarz Towarzystwa imienia Elizy Orzeszkowej, przyszły wydawca korespondencji autorki Meira Ezofowicza i opiekun zbiorów rękopiśmiennych zgromadzonych w Towarzystwie ${ }^{5}$. W opracowaniu kilku tomów tej edycji brał udział także docent Katedry Historii Literatury Polskiej UW, Stanisław Adamczewski (1883-1952), który jednakże, z nieznanych powodów, nie figuruje na stronach redakcyjnych. Prospekt subskrypcyjny zapowiadał 30 woluminów (a więc wybór). W roku 1937 ukazało się 10 pierwszych tomów Pism. W tomie 1 zamieszczono artykuł Eliza Orzeszkowa pióra Jarosława Iwaszkiewicza. W roku 1938 opublikowano tomy 11-20, a w r. 1939 tomy 21-246 . Dalsze prace przerwała druga wojna światowa. Świderski zginął w Auschwitz w 1941 r., dwa lata później w okupowanej Warszawie zmarł Drogoszewski.

Można śmiało postawić tezę, iż kontynuacją przedwojennego przedsięwzięcia pod patronatem PAL były 52 tomy Pism zebranych, które są najpełniejszą dotąd edycją dorobku Orzeszkowej. Ukazywały się w latach 1947-1953, najpierw w Spółdzielni Wydawniczej „Wiedza”, a potem w oficynie „Książka i Wiedza”, pod redakcją Juliana Krzyżanowskiego ${ }^{7}$. Opieka Krzyżanowskiego nad edycją była raczej ogólna: dotyczyła całościowych decyzji i niektórych ważnych, konkretnych rozstrzygnięć. Większość tomów opracował edytorsko młody wówczas adept dyscypliny, a późniejszy wybitny znawca twórczości Orzeszkowej - Edmund Jankowski (z pomoca zastępu redaktorów wydawniczych), ale $z$ niewiadomych przyczyn o jego roli w tym potężnym przedsięwzięciu rzadko się mówi i pisze.

5 Biogram Ludwika Brunona Świ ders ki e g o - zob. Polski słownik biograficzny. T. 51. Warszawa-Kraków 2016-2017. Serdeczne koleżeńskie wspomnienie (z wyszczególnieniem prac młodego uczonego) poświęcił Świderskiemu tuż po zakończeniu wojny A. Si e c z k o w s ki (Ludwik Brunon Świderski. „Pamiętnik Literacki” 1946, z. 3/4), który o jego warsztacie pracy pisze następująco: „Świderski powiększa jeszcze te zbiory [tj. zbiory autografów Orzeszkowej zgromadzone przez Towarzystwo imienia pisarki - I. W.], nawiązując kontakt z różnymi osobami, które mogą mu udzielić ustnych informacji; jeździ w tym celu do szeregu miast, najczęściej do Grodna i Wilna. Nominalnie pod kierunkiem prof. Ujejskiego i przy współudziale sędziwego prof. A. Drogoszewskiego, w istocie zaś rzeczy własną głównie praca - przygotowuje komentowany, pomysłowo ułożony zbiór listów Orzeszkowej oraz pełną edycję jej pism [tu omyłka, edycja była wyborem - I. W.]. Gabinet młodego polonisty zamienia się niemal w muzeum wielkiej pisarki. Autografy, portrety, pierwodruki, własne artykuły [...]. [...] posegregowane teczki, pokatalogowane notatki, wyraźnym charakterem gęsto zapisane i opatrzone dokładnymi tytułami zeszyty, arkusze i karteluszki [...]” (ibidem, s. 395). Warto podkreślić, że Świderski zaczął pracować nad edycją Pism mając zaledwie 23 lata! Równocześnie przygotował trzy tomy Listów Orzeszkowej, które ukazały się w latach 1937-1938; opublikował też kilkadziesiąt artykułów prasowych poświęconych głównie życiu i twórczości autorki Nad Niemnem.

6 Zawartość poszczególnych tomów zob. Nowy Korbut (t. 17, vol. 2), poz. 473. W Pismach Drogoszewski i Świderski zrezygnowali z prawie połowy dorobku Orzeszkowej. Pominęli (nie licząc fragmentów poetyckich, dramatu, krytyki literackiej, publicystyki, epistolografii i przekładów) następujące utwory: Z życia realisty (1868); Na prowincji (1869); Syn stolarza (1868); Pan Graba (1869); Cnotliwi (1869); Pamiętnik Wacławy (1870); Pajęczyna (1870); Wesoła teoria i smutna praktyka (1872); Na dnie sumienia (1872); Rodzina Brochwiczów (1873); Eli Makower (1874); Pompalińscy (1875); Maria (1876); Zygmunt Ławicz i jego koledzy (1882); Ardelion (1882); Z pożogi (1885-1886); Czciciel potęgi (1889); Chwile (1901); I pieśń niech zapłacze (1904); Z myśli wieczornych; fragmenty powieściowe zachowane w rękopisach (np. Beata) i sporo innych drobniejszych rzeczy.

7 Zawartość poszczególnych tomów zob. Nowy Korbut (t. 17, vol. 2), poz. 478. 
Czy wymienione tu edycje odpowiadają - przynajmniej częściowo - temu, co obecnie w tekstologii określamy terminem (niesłychanie trudnym do zdefiniowania) „wydanie krytyczne”? Nie sposób w krótkim artykule omówić wszystkich trzech edycji. Skupimy się więc, nie bez powodu, na Pismach Orzeszkowej z lat 1937-1939. Warto sprawdzić, jak zostały „zrobione”, dziś bowiem znamy jej twórczość przede wszystkim z tego wydania, przedrukowanego w całości (i prawie bez zmian) w powojennych Pismach zebranych.

Jak Drogoszewski i Świderski rozumieli edytorstwo naukowe? Drogoszewski miał za soba jedno zbiorowe wydanie dzieł pisarki, a więc sporo edytorskiego doświadczenia. Świderski był w tej materii nowicjuszem, ale człowiekiem niewiarygodnie wprost pracowitym, a przy tym zapalonym miłośnikiem twórczości Orzeszkowej i pracy archiwalnej.

Nie wiadomo dokładnie, kto pierwszy wyszedł z inicjatywą wydania Pism. Dużą rolę odegrało tu - jak już wspomniano - Towarzystwo imienia Elizy Orzeszkowej. Jednak wolno przypuszczać, że dla oficyny Gebethner i Wolff było to przedsięwzięcie czysto komercyjne. Firma ta wypuściła właśnie na rynek Pisma Bolesława Prusa w 26 tomach - także pod patronatem Polskiej Akademii Literatury, a pod redakcją Ignacego Chrzanowskiego i Zygmunta Szweykowskiego (Warszawa 19341936) - które się doskonale sprzedawały ${ }^{8}$. Można sądzić, iż propozycja opracowania dzieł kolejnego klasyka odpowiadała rzutkim wydawcom. Jedna z recenzentek Pism Orzeszkowej stwierdzała w 1938 r. wprost: najpierw firma Gebethner i Wolff zrobiła eksperyment w postaci zbiorowego wydania Prusa, które rozeszło się tak szybko, że zabrakło kompletów, zostały pojedyncze utwory. Podjęto się więc edycji dzieł Orzeszkowej ${ }^{9}$. Słowo wstępne, sygnowane przez Polska Akademię Literatury, czyli patrona obu edycji, prezentuje sprawę podobnie, choć w oświetleniu nie komercyjnym, ale ideowym. Akademia informuje w pierwszym tomie Pism Prusa, że inicjatywa wydawania serii klasyków polskich wynika $z$ braku w bibliotekach utworów najlepszych naszych prozaików drugiej połowy XIX w. i że problemowi temu postarała się zaradzić firma Gebethner i Wolff, realizując przedsięwzięcie pod patronatem PAL, która deklaruje: „Przyjęliśmy ten zaszczytny protektorat najchętniej, w jasnym zrozumieniu, że ci prawdziwie nieśmiertelni pisarze już za życia ziemskiego stanowili akademię literatury polskiej [...]"10. Tak więc Orzeszkowa była drugim po Prusie twórcą, którego zdecydowano uhonorować serią dzieł zebranych - współfinan-

8 Uderzająca jest analogia między tymi inicjatywami wydawniczymi. Pisma Prusa i Pisma Orzeszkowej ukazały się w latach trzydziestych u Gebethnera i Wolffa. Po zakończeniu drugiej wojny postanowiono opublikować jednocześnie zbiorowe edycje utworów obojga autorów. „Pisma pod redakcją Zygmunta Szweykowskiego (1948-1952) w 29 tomach stanowiły zasadniczo powtórzenie edycji przedwojennej z tą różnica, iż uzupełniono ją o trzy tomy" - pisze B. O b s u le w i c z - N i e w i ń s k a (Wstęp do „Pism wszystkich”. W: B. Prus, Pisma wszystkie: Humoreski, nowele, opowiadania. T. 1: 1864-1874. Red. T. Żabs ki. Oprac. T. Żabski, E. Lubczyńs ka-Jeziorna, H. Kubicka, A. Kuniczuk-Trzcinowicz. Wstęp T. Żabski. Warszawa-Lublin 2014, s. 6). Tak więc przedrukowane przedwojenne wydania Gebethnerowskie Prusa i Orzeszkowej posłużyły kilku powojennym pokoleniom.

9 Zob. I. Pannenkowa, Renesans Orzeszkowej. Pisma Elizy Orzeszkowej pod redakcja Drogoszewskiego i Świderskiego. Nakład Gebethnera i Wolffa. „Polonia” (Katowice) 1938, nr 4920.

10 Pisma Bolestawa Prusa. Red. I. Chrzanowski, Z. Szweykowski. T. 1. Warszawa 1935, s. 5 . 
sowaną przez Skarb Państwa. Edycją Pism opiekował się reprezentujący Dział Wydawniczy firmy Gebethner i Wolff redaktor Adam Bułakowski (1895-1939), który współpracował ze Świderskim i Drogoszewskim ${ }^{11}$.

Nieco głębiej za kulisy pracy nad Pismami pozwalają zajrzeć zachowane w Archiwum Elizy Orzeszkowej Instytutu Badań Literackich PAN w Warszawie materiały. Korespondencja Świderskiego i Drogoszewskiego z lat 1936-1939 (AEO, sygn. 1085) wskazuje, że próbowali oni pracować nad tomami solidarnie, ale inne materiały świadczą, iż większość obowiązków spadła na barki młodego uczonego ${ }^{12}$. Przepisane teksty dostarczała edytorom wynajęta przez firmę Gebethner i Wolff maszynistka. Drogoszewski z wieloma decyzjami Świderskiego, zwłaszcza jeśli chodzi o modernizację, nie zgadzał się i korygował młodego edytora, ale mimo wszystko chwalił go jako „cudownego współpracownika”. Świderski zaś miał z Drogoszewskim sporo kłopotów: ten spóźniał się z oddawaniem kolejnych tomów, a potem korekt do drukarni (na co redaktorzy z wydawnictwa bardzo narzekali), nie zwracał też na czas wypożyczonych przez Świderskiego z różnych bibliotek roczników czasopism, książek i rękopisów. Przez trzy lata (1936-1939) Świderski był wprost uwiązany przez pracę nad Pismami, wydawcy nie zgodzili się nawet na planowany przezeń kilkumiesięczny pobyt za granica, gdyż obawiali się, że edycja „polegnie”.

Korespondencja między Drogoszewskim a Świderskim pozwala także zrekonstruować w pewnej mierze ich warsztat edytorski. Obaj panowie prowadzili (przy wsparciu osób pomagających doraźnie) szeroko zakrojone poszukiwania bibliograficzne. Nie dotyczyły one tylko śladów przedruków poszczególnych utworów, ale także ustalenia korpusu twórczego Orzeszkowej. Przystępując do wydania jej dzieł edytorzy nie wiedzieli, ile tak naprawdę Orzeszkowa napisała, nie byli pewni, czy znają wszystkie jej powieści i nowele (nie mówiąc o kolejnych wydaniach czy przedrukach $\mathrm{w}$ periodykach, które w minimalnym zakresie uwzględniała pobieżna i niewolna od omyłek bibliografia Gabriela Korbuta). Działania edytorskie przy braku pełnej bibliografii autora to bardzo ryzykowne przedsięwzięcie. Obaj zdawali sobie $z$ tego sprawe i była to zapewne jedna z przyczyn decyzji o opracowaniu wyboru, a nie edycji całościowej. Świderski próbuje to nieco pokrętnie uzasadnić w pierwotnej wersji wstępu do Pism ${ }^{13}$ :

Pierwsze wydanie Pism Orzeszkowej w niepodległej Polsce zrywa świadomie i zdecydowanie z konwencjonalnym traktowaniem jej twórczości. Odrzuca ponętną z innych względów myśl wydania Orzeszkowej całej [...]. Trzeba przede wszystkim przełamać niesłuszną niechęć do wielkiej pisarki, niechęć powstałą wskutek nieznajomości jej najdoskonalszych rzeczy. Najpierw społeczeństwo musi się przekonać do tej wielkiej twórczości, musi w niej zasmakować - a wtedy samo zażąda Orzeszkowej całej, bo poznawszy i wchłonąwszy Orzeszkową istotną, będzie chciało poznać tę drogę, którą ona weszła na szczyty. [k. 7-8]

Nie sposób nie odnieść wrażenia, że fragment ten (który ostatecznie nie znalazł

11 Zob. listy firmy Gebethner i Wolff do L. B. Świderskiego, z lat 1937-1938 (AEO, sygn. 1091).

12 Zob. m.in. maszynopisy utworów Orzeszkowej z własnoręcznymi poprawkami i dopiskami Świderskiego (AEO, sygn. 1170) oraz maszynopisy wstępów i not bibliograficznych do większości tomów Pism - także z uwagami, dopiskami i poprawkami korektowymi Świderskiego (AEO, sygn. 1171). 
się w druku) to „dorobione” tłumaczenie - podjętej na jakiejś innej podstawie - decyzji. Wpływ na nią mogły mieć także względy techniczne. Firma Gebethner i Wolff ograniczyła edycję do określonej liczby arkuszy, która zamykała się właśnie w około 30 tomach; całość dorobku pisarki musiałaby obejmować ich niemal dwa razy tyle. To - dla wydawcy mającego nadzieję na zysk - było zbyt wielkie ryzyko.

Świderski wydobywał z bibliotek, archiwów i zbiorów prywatnych autografy utworów Orzeszkowej. Obaj z Drogoszewskim przeglądali je, porównywali z edycja$\mathrm{mi}$ i na tej podstawie nanosili poprawki na maszynopisowe transkrypcje. Świderski przygotowywał noty bibliograficzne do kolejnych tomów, przesyłał je do akceptacji i ewentualnych poprawek Drogoszewskiemu. Obowiązkiem tego pierwszego było też dostarczanie kompletów czasopism $\mathrm{z}$ wydaniami utworów pisarki (co wymagało częstych wyjazdów np. do Krakowa czy do Wilna). Obaj edytorzy wspólnie ustalali układ i kolejność tomów. Obaj robili korektę dostarczanego z drukarni składu. Czasem miewali rozbieżne zdania: czy trzymać się „bliżej” autografu, czy też raczej wersji drukowanych. Przygotowując utwór $W$ zimowy wieczór, Drogoszewski informuje Świderskiego, że w pewnych miejscach pozostawił tekst drukowany, wbrew rękopisowi (list z 7 III 1938). Innym razem powiadamia go:

Skończyłem właśnie Australczyka. Znacznej części (końcowej) w autografie brak, ale w środku żadnych luk nie ma. Zgadzam się z tym, że niejedno trzeba zostawić tak jak jest w tekście drukowanym, mimo to w wielu wypadkach zbliżyłem się bardziej do autografu niż Pan projektował [...]. [list z 9 XI 1938, Warszawa]

Większość uwag Drogoszewskiego wskazuje, że nie wahał się on kompilować różnych przekazów, aby dotrzeć do tekstu „autentycznego”.

Koncepcja układu Pism miała być początkowo inna niż ostatecznie przyjęta. Informuje o tym kolejny z zarzuconych wariantów wstępu Od Redakcji ${ }^{14}$. Projekt już przemyślany i domknięty - zmieniono zapewne w trakcie pracy (nie wiadomo jednak, na jakim etapie i za czyją sprawa). Pierwotnie planowano 27 tomów (nie 30 - jak w wersji ostatecznej). Świderski (autor wstępu) nazywa to wydanie pełniejszym niż dotychczasowe edycje obrazem twórczości Orzeszkowej „wskutek bardziej racjonalnego wy b or u u tw or ów" (s. 1). Deklaruje pominięcie publicystyki i dzieł dramatycznych, wyjaśnia następnie, z czego zrezygnowano i dlaczego ograniczono zakres wczesnej beletrystyki (odpadły Pan Graba, Pamiętnik Wacławy, Eli Makower, Sylwek Cmentarnik), niektóre $z$ utworów, jak Pamiętnik Wacławy, pominięto ze względu na rozmiar (Pamiętnik zająłby 4 tomy i zabrałby tym samym miejsce innym, lepszym utworom - argumentuje Świderski). Redaktorzy chcieli wszakże dać publiczności kilka od dawna nie wznawianych dzieł z wczesnego okresu, jak np. Rodzina Brochwiczów, Zygmunt Ławicz i jego koledzy (których w rezultacie w Pismach nie uwzględniono) czy Pierwotni. $Z$ okresu najpóźniejszego miały odpaść: Czciciel potęgi, Argonauci i Ad astra (te dwie ostatnie powieści weszły jednak do Pism). Wstęp proponuje układ chronologiczny w przeciwieństwie do poprzedniego wydania utworów Orzeszkowej z lat 1912-1914, skomponowanego tematycznie. Do serii plano-

14 Maszynopisy wstępu i not bibliograficznych do Pism Orzes zkow ej. AEO, sygn. 1171. Co ciekawe, ten wariant wstępu jest korektową wersją maszynopisu, przygotowaną do składu. Musiał zostać wycofany w ostatnim momencie. 
wano włączyć dwa fragmenty prozatorskie (dzisiaj kompletnie zapomniane, bo nigdy nie wznawiane): Wspomnienia z powiatu pińskiego i Angina pectoris (ostatecznie się w Pismach nie znalazły). Redaktorzy postanowili zrezygnować $\mathrm{z}$ wydawania utworów zachowanych tylko w rękopisach (np. Ardeliona - bo jest on niedokończony i nadaje się raczej do celów naukowo-badawczych) ${ }^{15}$.

Metoda pracy z przekazami i towarzyszące im podstawy teoretyczne zostały jedynie szkicowo zarysowane we wstępie redakcyjnym do tomu 1 Pism. Czytamy tu, że edycja ma ambicje „dania po raz pierwszy Orzeszkowej a u t e n ty c z n ej” 16 _ co ma oznaczać tekst wolny nie tylko od „wycinanek” cenzury, ale przede wszystkim oczyszczony z ingerencji „bezimiennych poprawiaczy” (redaktorów czasopism, korektorów, wydawców), którzy w kolejnych edycjach nie tylko zmieniali formy językowe, słowa i szyk wyrazów, ale niejednokrotnie wyrzucali całe zdania, a nawet akapity. Pisma powstawały pod hasłem „odgrzebania” Orzeszkowej spod drugiej redakcyjnej - cenzury (czy też „prywatnej cenzury polskiej” - jak nazwał to zjawisko Konrad Górski ${ }^{17}$ ), której istnienie pisarka sama zdiagnozowała na wczesnym etapie twórczości. Drogoszewski i Świderski zapowiadają „gruntowne odtworzenie autorskiego tekstu" m.in. poprzez przywracanie (na podstawie autografów) niektórych "dziwolagów gramatycznych”, regionalizmów i form osobniczych z języka Orzeszkowej. Zdają sobie sprawę, że nie zawsze zachował się rękopis, w tych wypadkach deklarują ( z zabawną dziś szczerością), że będą odtwarzać „przypuszczalne brzmienie pierwotne”, ale tylko wtedy, gdy wyczuja „lwi pazur” poprawiaczy. Na tym kończy się w zasadzie informacja o specyfice pracy edytorskiej nad Pismami. Można ją dokładniej poznać na podstawie innych źródeł. Metodologię Drogoszewskiego i Świderskiego pozwalają zrozumieć w pewnym stopniu noty bibliograficzne dołą-

Zapowiadany w zarzuconym wstępie Od Redakcji układ tomów przedstawiał się następująco: 1 - Wspomnienia z powiatu pińskiego, Poczatek powieści, W klatce; 2 - Na prowincji; 3 - Marta; 4 - Rodzina Brochwiczów; 5 - Rodzina Brochwiczów; 6 - Meir Ezofowicz; 7 - Meir Ezofowicz; 8 $Z$ różnych sfer; 9 - Z różnych sfer; 10 - Z różnych sfer; 11 - Zygmunt Ławicz; 12 - Pierwotni; 13 Stare obrazki; 14 - Mirtala; 15 - Niziny, W zimowy wieczór, Tadeusz; 16 - Dziurdziowie; 17 - Nad Niemnem; 18 - Nad Niemnem; 19 - Cham; 20 - Jędza, Bene nati; 21 - Dwa bieguny; 22 - Melancholicy; 23 - Melancholicy; 24 - Australczyk; 25 - Pieśń przerwana, Anastazja; 26 - Gloria victis; 27 - Gloria victis (AEO, sygn. 1171, s. 2). Spośród wymienionych tytułów do ostatecznej wersji Pism nie weszły: Wspomnienia z powiatu pińskiego, Na prowincji, Rodzina Brochwiczów, Zygmunt Ławicz i jego koledzy, Stare obrazki. Dodano natomiast: Obrazek z lat głodowych, Argonautów, Ad astra oraz zbiory opowiadań Panna Antonina, Iskry, Przędze.

Od Redakcji. W: E. Orzeszkowa, Pisma. Red. A. Drogoszewski, L. B. Świderski. T. 1: Pierwsze utwory. Warszawa 1937, s. 19.

Zob. K. Gó r s k i, Zbiorowe wydanie pism Orzeszkowej. „Słowo” (Wilno) 1937, nr 85. Górski konstatuje tu, że nasi pozytywistyczni pisarze ucierpieli bardziej niż twórcy innych epok od owej podwójnej cenzury: urzędowej rosyjskiej oraz polskiej, stosowanej przez wydawców, redaktorów czasopism „i wreszcie korektorów językowych, sprawujących swą władzę w firmach wydawniczych i redakcjach”. Jako przykład Górski przytacza fragment listu M. Ilnickiej do S. Krzemińskiego (który robił korektę jednej z powieści Kraszewskiego). Redaktorka „Bluszczu” radzi, by Krzemiński usuwał ile się da słów brzydkich - jak on a sama robi zaws ze. Górski stawia tezę: „tekst dzieł literackich drugiej połowy XIX wieku bardzo często nie odpowiada intencjom twórczym autorów lub, innymi słowy, nie znamy tych pisarzy w rzeczywistej ich postaci”. Dodaje jednak zaraz: „Nie łudźmy się zresztą, że uda nam się dotrzeć do tego nieskażonego narzuconymi poprawkami czystego tekstu". 
czone do poszczególnych tomów, a także komentarze obu edytorów zawarte w publikowanych w prasie artykułach.

W polemice Drogoszewskiego z recenzja pierwszej partii Pism Orzeszkowej pióra Leona Piwińskiego pojawia się (podobnie jak we wstępie Od Redakcji) termin „t e k s t a u te n ty c z ny”18. Piwiński najwięcej uwagi poświęcił metodzie ustalania tekstu, i metodę tę skrytykował, dowodząc, że redaktorzy wyszli z błędnych założeń, przywracając za autografami i pierwodrukami wyraźne błędy językowe i niezręczności stylowe. Radzi trzymać się „przyjętej dziś ogólnie zasady edytorskiej, że obowiązuje ostatni tekst wydany za życia autora i z jego wiedza”. „Nie, pójdziemy raczej ścieżką utorowaną przez prof. Szweykowskiego" - odpowiada na zarzut Drogoszewski, nawiązując do sposobu pracy edytora Gebethnerowskiego wydania Pism Prusa. Ujawnia tym samym wzorzec, który można dziś określić jako zasadę wprowadzania form autorskich do tekstów wydań późniejszych ${ }^{19}$. Następnie pyta:

Jaki tekst jest autentyczny? Czy pierwotny, czy po latach zmieniony? Ad[am] Czartoryski napisał w końcu w. XVIII Barda polskiego. Po latach zmienił i wydrukował. Dziś drukują oba teksty jako dwa odrębne utwory. Lecz za autentyczny uważamy pierwszy, rękopis wieczny...

- i podkreśla, że przy edycji Mirtali wybrali ze Świderskim pierwszą wersję powieści, choć Orzeszkowa przy kolejnym wydaniu zmieniła tekst. Na purystyczno-poprawnościowe zarzuty Piwińskiego odpowiada Drogoszewski pytaniem: „Czy należy podawać tekst autentyczny, będący własnością autora, zachowujący wszelkie właściwości indywidualnego i regionalnego języka i stylu? Czy też należy poszukiwać tekstu tzw. poprawnego?" Najwyraźniej pojmuje edytorstwo jako docieranie do przekazu, który był najbliżej intencji autorskiej. Niestety, nie tłumaczy dokładniej sposobów konstruowania tego a u tenty c zn e go przekazu. Przekonanie Drogoszewskiego wynika $\mathrm{z}$ założenia, że Orzeszkowa nigdy nie przeprowadzała korekty własnych utworów (co nie jest do końca prawda), które potem poprawiali wydawcy i redaktorzy, „dumni ze swych starań, pewni, że chronia autorkę (jak autorów w ogóle) przed kompromitacją". Z postawy tej wyniknęło - jak twierdzi Drogoszewski - jedynie utrwalanie poczucia indywidualności korektorów.

Wyobrażenie o technice pracy edytorskiej i świadomości tekstologicznej Świderskiego daje nota bibliograficzna do Meira Ezofowicza (opublikowanego w tomach 4 i 5 Pism (Warszawa 1937)) oraz artykuł Jak spreparowano „Meira Ezofowicza - będacy pokłosiem pracy nad edycją tej powieści ${ }^{20}$. Świderski porównał autograf Meira (zachowany w Bibliotece Ordynacji Krasińskich, dziś zaginiony) z innymi wydaniami i skonstatował:

znany dotychczas tekst Meira nie jest tekstem autentycznym, gdyż przed wydrukowaniem w „Kłosach” powieść ta została w swoisty sposób spreparowana: wycinano w niej całe ustępy mogące nie podobać

Recenzję L. Piwińskiego opublikowało „Życie Literackie” (1938, nr 1), polemikę zaś A. D r og o s z ew s ki e g o, Kilka uwag o wydaniu zbiorowym „Pism” E. Orzeszkowej - „Tygodnik Ilustrowany" (1938, nr 21).

19 W pierwszym tomie Pism Or ze s z k ow ej (s. 24) znajduje się nota z podziękowaniami - m.in. dla Z. Szweykowskiego: za „ochotne dzielenie się doświadczeniem nabytym przy rekonstrukcji tekstów Prusa".

L. B. Świ de r s ki, Jak spreparowano „Meira Ezofowicza”. „Prosto z Mostu” 1937, nr 19. 
się tym, których [Orzeszkowa] opisywała. [...] Pierwszym autentycznym wydaniem jest edycja niniejsza, oparta na autografie. Odbiega od niego jedynie w podziale powieści na dwa tomy - koniecznym tu ze względów technicznych - którego nie zna rękopis ${ }^{21}$.

Wedle Świderskiego ów rękopis (brulionowy - ze skreśleniami) stanowił „ostateczną redakcję powieści”. Edytor jest świadom, że pierwodruk w Lewentalowskich „Kłosach” nie opierał się bezpośrednio na zachowanym autografie, lecz na (niezachowanej) kopii. Mimo to uznaje arbitralnie ow brulion za czystopis (zapewne dlatego, że służył za podstawę wykonania kopii). Wiadomo wszakże skądinąd, że Orzeszkowa sczytywała kopie i często wprowadzała spore zmiany w tekście otrzymanym od przepisywacza. Być może, w pierwodruku znalazło się coś, co dodała w kopii, a czego brak w autografie-brulionie. Świadomość edytorska Świderskiego jednak nie bardzo rozróżnia status tych dwóch rękopisów. Skoro autograf z Biblioteki Krasińskich był brulionem - jak można twierdzić, że oparte na nim wydanie jest pierwszym autentycznym? Przyjąwszy ten przekaz za źródło edycji, Świderski spreparował Meira po raz drugi po Lewentalu (który z obawy przed antysemicką wymową dzieła postanowił „wykorzystać ołówek redakcyjny” i usunąć z utworu najbardziej drażliwe miejsca). Preparowanie to - zamierzone, związane $z$ wiara w „tekst autentyczny” - polega na „montowaniu” czegoś, co nigdy nie istniało, na wprowadzaniu do pierwodruku (opartym na czystopisowej kopii) pominiętych fragmentów $z$ autografu-brulionu. Tekst zostaje zmodernizowany wedle założeń reformy ortograficznej z 1936 r., przy czym - jak wcześniej wspomniano - zachowuje się pewne właściwości języka pisarki, które niekoniecznie się z ową normą zgadzają.

Analiza not do poszczególnych tomów Pism potwierdza, że dla Drogoszewskiego i Świderskiego głównym punktem odniesienia był autograf, tam zaś, gdzie go brakło - pierwodruk. Od zasady editio princeps odchodzą oni, gdy w pierwodruku znajdzie się zbyt dużo błędów zecerskich lub gdy np. późniejsze wydanie książkowe charakteryzuje się jakąs edytorska zaletą (choćby przywróceniem fragmentów skreślonych przez cenzurę, jak w przypadku jednego $z$ tomów $Z$ różnych sfer). Jest sporo sytuacji, w których autorzy z naukową dumą deklarują kompilację dwóch przekazów, jakby „zlepek” dwóch podstaw. Tak więc np. opowiadanie Stracony oparto na pierwszym wydaniu książkowym, jednak niektóre formy przywrócono za wydaniem prasowym, uznając je za bliższe intencji autorki; tekst Widm edytorzy ustalili biorąc pod uwagę pierwodruk prasowy i edycję wileńska, nie wyjaśniają jednak, co zaczerpnięto z którego wydania. Bardzo ciekawym przypadkiem są Pierwotni (tom 9 Pism). Edytorzy informują, że pierwsze wydanie utworu w „Tygodniku Mód i Powieści” zostało mocno „wystrzyżone” przez redaktora Kaszewskiego, który usunął zdania mogące razić uczucia religijne. W publikacji książkowej z $1884 \mathrm{r}$. Orzeszkowa wymogła na Lewentalu przywrócenie wszystkiego, co wykreślono w „Tygodniku”. Edytorzy wymieniają owe fragmenty, a to dowodzi, że kolacjonowali pierwodruk i wydanie książkowe. Zasadniczo przyjmuja za podstawę edycję Lewentalowska z $1884 \mathrm{r}$., ale przywracają wiele form językowych za pierwodrukiem, a także - za tymże pierwodrukiem - fragmenty opuszczone w wydaniu książkowym

21 L. B. Świderski, nota bibliograficzna w: Orzeszkowa, Pisma, t. 4: Meir Ezofowicz (1937), s. 199. 
z powodu niedbałej korekty. Kolejnym frapujacym exemplum obróbki edytorskiej jest Panna Antonina (t. 11 Pism), opracowana jednocześnie na podstawie pierwodruku i autografu, który podczas kolacjonowania okazał się brulionem. Edytorzy postanowili więc skompilować dwa przekazy. A...b...c... (tom 14 Pism) jest kontaminacją autografu-brulionu, będącego podstawą kopii, która z kolei posłużyła do przygotowania, niedokończonego, pierwodruku w „Świcie”, oraz nieco innej wersji tegoż opowiadania - czyli właściwego pierwodruku w „Gazecie Warszawskiej”. Edytorzy nie ujawniają wszakże, co czerpią z której wersji. Powieść Nad Niemnem (tomy 15-17 Pism) została opracowana na podstawie autografu-brulionu. Edytorzy informują w nocie, że odtworzyli autentyczny tekst utworu, zniekształcony przez korektora „Tygodnika Ilustrowanego” (w tym wypadku był to Wincenty Korotyński we własnej osobie): ,jedno z arcydzieł literatury polskiej odzyskało - w najdrobniejszych szczegółach - swój kształt autentyczny”. Drogoszewski i Świderski nic jednak nie wspominają o kopii, która była podstawą pierwodruku prasowego, ani o tym, co cenzura usunęła w wydaniu książkowym.

Przy kolacjonowaniu przekazów edytorzy Pism nie ograniczali się do wydań za życia Orzeszkowej (co stoi w sprzeczności z ówczesną normą, uznającą za wiarygodne te teksty, nad którymi autor mógł mieć kontrolę), przy porównywaniu brali pod uwage także edycje późniejsze. Po zakończeniu kolacjonowania „przywracają” jak pisza - tekst autografu lub pierwodruku, „poszarpany” przez późniejszych „poprawiaczy”. Niejasne natomiast - w jakim stopniu dokonuja przywrócenia owego „autentycznego” tekstu. W notach pojawia się nagminnie tajemnicza informacja: „tekst został poprawiony za pierwodrukiem” - co może oznaczać równie dobrze wprowadzenie kilku, jak i kilkuset poprawek. W Pismach nie ma tzw. aparatu, do którego przyzwyczaiły nas współczesne wydania krytyczne (opracowujący Pisma także używają wobec swego przedsięwzięcia określenia „edycja krytyczna”, operuja jednak wyraźnie innym wyobrażeniem krytyczności), czyli wykazu odmian, zestawienia koniektur i emendacji ${ }^{22}$, nie ma też żadnych informacji dotyczacych modernizacji pisowni oraz interpunkcji - poza ogólną zasadą, że dostosowuje się pisownię do „postanowień Komitetu Ortograficznego z czerwca 1936”. Edytorzy nie wspominają, czy mieli jakieś źródła pozwalające ustalić, co w wydaniu książkowym pochodziło od samowolnych „poprawiaczy”, a co było decyzja pisarki. Poziom kompilacji dokonanej w Pismach sprawdzić mogłaby wyłącznie mozolna dekonstrukcja, czyli ponowne porównanie wszystkich przekazów i wypunktowanie, co z którego zaczerpnęli edytorzy, tworząc właściwie nowy tekst. W wielu sytuacjach nie byłoby to jednak możliwe, gdyż autografy zostały zniszczone w czasie wojny.

Drogoszewski i Świderski postanowili w przypadku niektórych utworów zreali-

Drogoszewski i Świderski uważali, że rozbudowany aparat krytyczny w edycji Pism to niepotrzebny naddatek. W nocie poświęconej Mirtali deklarują, że ciekawe byłoby „wykazanie ewolucji”, która przebywają umysły autorskie (aluzja do zmian, jakich dokonała Orzeszkowa w drugim wydaniu Mirtali, i do jej wypowiedzi uzasadniających te zmiany zawartych w listach prywatnych), jednak wymagałoby to „zestawienia obu tekstów”, a to „przecież gra niewarta świeczki!” - podkreślają. „Pozostawałoby inne jeszcze wyjście: podanie wykazu skreśleń i - bardzo nielicznych - poprawek, ale na to znowu brak miejsca nie dozwala” (Pisma, t. $10\langle 1937\rangle$, s. 235). Być może, oficyna Gebethner i Wolff postawiła jakieś twarde warunki, jeśli chodzi o objętość tomów. Wola wydawcy często ogranicza koncepcje filologa. 
zować niezrealizowane zamiary konstrukcyjne Orzeszkowej - jak chociażby pomysł włączenia Widm do tomu 3 cyklu opowiadań $Z$ różnych sfer. Kompozycja kilku woluminów Pism może wydawać się przypadkowa, ale stanowi wynik prostej kalkulacji finansowej. Tak jest np. z tomem 22, zawierającym Pieśń przerwaną i Jędzę. Edytorzy wyjaśniają szczerze, że sama Pieśń przerwana była zbyt „szczupła”, „by mogła tworzyć osobny tomik niniejszej edycji” ${ }^{23}$. A ponieważ nie chciano pominać Pieśni ze względu na jej wartość artystyczną, więc połączono ją ze starszą o cztery i pół roku Jędza, zaburzając układ chronologiczny. Wielu recenzujących Pisma miało kłopot $\mathrm{z}$ doszukaniem się sensownego klucza w wyborze i kompozycji serii. Do tego grona zaliczała się Maria Dąbrowska, która pyta w swym felietonie: dlaczego - skoro wydano prozę debiutancka jak np. Obrazek z lat głodowych lub Ostatnia miłość - zrezygnowano z utworów dużo lepszych artystycznie, takich jak Mago Wielki, Czciciel potęgi, Eli Makower bądź Rodzina Brochwiczów ${ }^{24}$. Braki kompozycyjne serii wypunktował znakomicie Stefan Kołaczkowski. Opowiedział się przeciw wydaniu kompletnemu: „różnych Cnotliwych, Panów Grabów czy Pompalińskich możemy sobie darować" - pisze i proponuje rozpoczęcie całej edycji od Pamiętnika Wacławy. Twierdzi, że przyjęty układ wydaje się dowodem pewnego niezdecydowania oraz niedocenienia dzieł pisarki. Poważna lukę stanowi, jego zdaniem, brak Rodziny Brochwiczów (kapitalnego obrazu rozkładu rodzin ziemiańskich w latach siedemdziesiatych XIX w.) oraz Elego Makowera (ze względu na krytyczne koncepcje fundamentów kultury nowoczesnej, która rozpoczęła się od powszechnego dostępu do edukacji, pozwalającej wiele zdobywać, ale nie uczącej stawania się dobrym człowiekiem). Na pominięcie Sylwka Cmentarnika wpłynęło zapewne nieporozumienie co do pojmowania tzw. myśli postępowej u Orzeszkowej, a jest to jeden $z$ utworów, który umożliwia zorientowanie się $\mathrm{w}$ różnicach między humanitaryzmem XVIII-wiecznym a humanitaryzmem pisarki. Brakuje Kołaczkowskiemu Marii - która pozwoliłaby lepiej zrozumieć bezpośrednie skłonności autorki do postawy wyrzeczenia się, uosobione potem w postaci Seweryny ${ }^{25}$. $Z$ intencjami kompozycyjnymi edytorów utożsamił się natomiast Eugeniusz Januszkiewicz. Odpowiadając na pytanie, dlaczego wydanie prezentuje słabe utwory debiutanckie, a pomija masę dobrych, pisze:

Selekcja pism do wydania Gebethnerowskiego odbywała się [...] przez dwa sita. Z początku musiał nastapić podział na grupy według problematyki. Następnie w obrębie tych grup wybierano rzeczy najlepsze pod względem artystycznym. W ten sposób odpadły wprawdzie rzeczy niejednokrotnie lepsze, a znalazły miejsce utwory słabsze, ale otrzymaliśmy za to zbiór pism reprezentatywnych dla całości problematyki Orzeszkowej i dający z zakresu każdego problematu rzeczy najlepsze ${ }^{26}$.

Edytorską ambicją Pism było zaprezentowanie tekstu „autentycznego”, najbliższego autorskiej intencji, której poszukiwano w autografach i pierwodrukach. Nowoczesna wówczas metoda kolacjonowania zachęciła w jakiś sposób edytorów do tworzenia kompilacji, montowania nieuchwytnych splotów tekstowych. Razi 
nieco zaufanie Drogoszewskiego i Świderskiego do autografów. Wszystkie, które opisują i które przyjmuja za podstawę, to autografy-bruliony. Uznanie takiego przekazu za najbliższy intencjom autorskim jest nadużyciem. Nie na brulionach bowiem opierały się pierwodruki, ale na czystopisach oraz czystopisowych kopiach a te niemal wszystkie zaginęly w redakcjach.

Dlaczego warto poświęcić koncepcji Drogoszewskiego i Świderskiego trochę uwagi? Odpowiedź jest prosta: ponieważ znamy Orzeszkową w tej właśnie wersji i w standardzie edytorskim $z$ początku XX wieku. Edycja została - jak już wspomniano - w całości (i prawie bez zmian) włączona do wydanych tuż po drugiej wojnie 52 tomów Pism zebranych pod redakcją Krzyżanowskiego (jest to po dziś dzień tekstowy punkt odniesienia dla wszystkich „poważnych” czytelników Orzeszkowej). Krzyżanowski i jego współpracownicy nie ukrywają tego faktu - informacja znajduje się w notach edytorskich do poszczególnych tomów. A jednak nie jest to wiedza powszechna, na ogół uznaje się Pisma zebrane za twór osobny. Dlaczego Krzyżanowski zdecydował się na przedruk wydania $z$ lat 1937-1939 z dobrodziejstwem inwentarza? Tuż po wojnie standardy edytorskie zastosowane przez Drogoszewskiego i Świderskiego nadal uchodziły za nowoczesne. Warunki w zniszczonym kraju nie pozwalały na taki wysiłek naukowy, na jaki mogli sobie pozwolić Drogoszewski i Świderski pod opieka Gebethnera i Wolffa. Potraktowano więc Pisma zebrane jako dokończenie niedopełnionej edycji przedwojennej. We wstępie Krzyżanowski daje przegląd dotychczasowych wydań zbiorowych Orzeszkowej, aby umiejscowić na ich tle swoją edycję. Wspomina o wydaniu Lewentalowskim (1884-1889), Wawelbergowskim (1899), o opracowanym przez Drogoszewskiego wydaniu rozpoczętym w r. 1912 (które nazywa „nieudałym przedsięwzięciem”). Pisma z lat 1937-1939 określa jako „wydarzenie niecodzienne”:

Po raz mianowicie pierwszy spróbowano tutaj zamiast niechlujnego przedruku, powtarzającego narastające latami błędy i przekręcenia tekstu, dać wydanie staranne, popularne wprawdzie, lecz zarazem naukowe, oparte na tekstach sprawdzonych, odtwarzających intencje autorskie. [...] Podobnego opracowania nie miał przed r. 1937 żaden z klasyków naszej prozy powieściowej, wydania bowiem zbiorowe Sienkiewicza, Reymonta, Żeromskiego i in. sporządzało się byle jak, w myśl zasady „byle handel szedł"27.

Krzyżanowski ocenił wysoko zaangażowanie i koncepcje Świderskiego (którego wymienia jako jedynego autora edycji, pomijając zupełnie - $z$ niewiadomych powodów - Drogoszewskiego). Widzi równocześnie w pracy Świderskiego kilka „niedomagań”. Zarzuca mu np., że jego posłowia nie zawsze operowały wystarczającym materiałem bibliograficznym. Zarzut to zdumiewający wobec faktu, że Krzyżanowski i Jankowski - który był edytorskim wykonawcą Pism zebranych - nie wyszli ani na krok poza osiagnięcia Świderskiego, jeśli idzie o badanie czy przywoływanie źródeł, a najlepsze noty edytorskie w Pismach zebranych to te przedrukowane z Pism. Kolejny zarzut Krzyżanowskiego dotyczy wprowadzania zbyt daleko idących poprawek tekstowych: Świderski umiejętnie docierał do przekazów, ale nie zawsze 1953, s. LI. 
udawało mu się wybrać trafnie; czasem wybierał z pośpiesznego autografu-brulionu pisarki wersję niezrozumiała językowo, ewidentnie zawierającą błąd, w pierwodruku już usunięty. Skopiowanie całego wydania Pism uzasadnia Krzyżanowski następująco:

wydanie Świderskiego przyniosło pisma Orzeszkowej w ujęciu tak dobrym, że teksty ich można było przenieść do wydania obecnego z nieznacznymi zmianami i podobnie wyzyskać jego posłowia, zaznaczając w nich jednak różnice, wywołane przez niszczenie źródeł, które jemu jeszcze były dostępne ${ }^{28}$.

Można przyjąć, że Krzyżanowski zaakceptował bez zastrzeżeń kompilacyjną metodę Świderskiego i Drogoszewskiego. Natomiast sygnalizowane tu poprawki jak dowodzi skolacjonowanie kilku utworów z obu wydań - ograniczył do naprawdę minimalnych ingerencji. Pozostałe (nie przedrukowane za Pismami) tomy Pism zebranych zostały przygotowane na podstawie najróżniejszych publikacji: począwszy od prasowych pierwodruków, poprzez Lewentalowskie „Tanie Zbiorowe Wydanie Pism", pojedyncze edycje książkowe, aż do nielubianej przez Krzyżanowskiego edycji rozpoczętej przez Drogoszewskiego tuż przed pierwszą wojną światową. Krzyżanowski deklarował, że jego seria ma charakter popularnonaukowy - z naciskiem na „autentyczność” i „poprawność” tekstów, którą rozumiał tak, jak rozumieli ją opracowujący przedwojenne Pisma. Na koniec nieco przewrotnie skonstatować wypada, że Pisma zebrane Orzeszkowej w 52 tomach nie są tym, za co je ma większość korzystających: w połowie sa przedrukiem, a autorem opracowania jest nie Julian Krzyżanowski, ale: Ludwik Brunon Świderski, Aureli Drogoszewski i Edmund Jankowski (z zespołem redaktorów Spółdzielni „Książka i Wiedza”).

W taki oto sposób Orzeszkowa istnieje dziś „tekstowo” w naszej świadomości. Trudno zestawić ową tradycje szukania przekazu „autentycznego”, budowania nowych tworów ze starej materii czy wiary w jedną wersję doskonała - z tym, czego doświadczamy współcześnie: natłokiem nowych teorii edytorskich i ciagłymi zmianami definicji tekstu. Krytyka genetyczna powoli, ale chyba skutecznie oduczyła edytorów „lepienia” doskonałych wersji, zakładając, że wszystkie przekazy są równie ważne w dochodzeniu do ostatecznej czystopisowej postaci. Najnowsze (i najmodniejsze w dyskursach anglosaskich, a ostatnio także wśród polskich badaczy) teorie porzuciły zainteresowanie intencją autora (który się wyraźnie „rozmył”) i uznały, że nie ma ostatecznej postaci tekstu, bo jest on zmienny, „płynny” (istnieje w wielu wersjach, które tworzy niekoniecznie sam autor, ale właśnie owi postponowani przez Drogoszewskiego i Świderskiego redaktorzy, wydawcy, korektorzy i cenzorzy). Co więcej, każdy przekaz danego utworu (za życia autora i po jego śmierci) jest równie istotny społecznie i kulturowo ${ }^{29}$. Gdy do pojęcia tekstu wprowadzono dynamikę zmian - kłopotem stało się przygotowanie takiej edycji, która uczyniłaby owa płynność widoczną dla odbiorcy. Jak jednak czytać wiele wersji naraz? - pyta John Bryant, propagator terminu „płynny tekst” i związanej z nim

Zob. J. M c G a n n, Social Values and Poetic Acts: The Historical Judgement of Literary Work. Cambridge 1988. Na polski przetłumaczono szkice J. Mc Gann a poświęcone edytorstwu w erze cyfrowej: Nowa Respublica Litteraria. Pamięć i nauka w wieku cyfryzacji. Przeł. P. B e m, Ł. C y b u lski, O. Mastela, J. Prus s ak. Warszawa 2016. 
teorii ${ }^{30}$. Zmienia się cel przygotowywania edycji: kładzie się nacisk na badanie kulturowych przyczyn zróżnicowania materii tekstowej jednego utworu. Nie wystarcza wyświetlanie wariantów, Bryant żąda od edycji, by zawsze była gotowa na przyjęcie kolejnego przekazu i by opowiadała historię jego odbioru. Nowe teorie nie lubią tradycyjnego edytorstwa (choć własnego modelu jeszcze w praktyce nie wypracowały), gdyż wymykają mu się wydania o autorstwie niepotwierdzonym (czyli właściwie większość przekazów). Można powiedzieć, że bohaterem edytorstwa klasycznego był autor i jego pomysły, a nowego - ma być tekst i jego dzieje, badanie, jak i dlaczego się zmieniał, a także lekturowe potyczki odbiorców.

Przedstawiony tu krótki rekonesans przeprowadzono w związku z rozpoczynającym się właśnie nowym projektem edycji dzieł zebranych Orzeszkowej ${ }^{31}$ i pytaniem: jak w obliczu owej koncepcyjnej „płynności” poradzić sobie z ogromem materiału i towarzyszącą mu wciąż żywą tradycją edytorską? Pytanie na razie pozostawiamy otwarte i liczymy, że odpowiedź pojawi się w miarę rozwoju prac projektowych.

\author{
Abstract \\ IWONA WIŚNIEWSKA Institute of Literary Research of the Polish Academy of Sciences, \\ Warsaw \\ ORCID: 0000-0001-7230-7552
}

\title{
ELIZA ORZESZKOWA'S WRITINGS-ATTEMPTS AT CRITICAL EDITIONS
}

The paper is trying to reconstruct, as based on printed and archive documents, the textological awareness and the editors' method applied to Orzeszkowa's collected works, namely Pisma (Writings) from the years 1937-1939 prepared by Aureli Drogoszewski and Ludwik Brunon Świderski, and Pisma zebrane (Collected Writings) published between 1947 and 1953, prepared by Julian Krzyżanowski and Edmund Jankowski, the latter of which until now is a basis of our knowledge in the writer's creativity. Considerations focus on the terms used by the editors: "critical edition," "authentic source," "editorial censorship." The aim of the research is a planned confrontation of the first half of the $20^{\text {th }}$ century editorial ideas with the latest textological and editorial conceptions (concentrating not on the author's intention but on the text history and changeability) for the needs of a new edition of Orzeszkowa's collected writings that started this year.

J. Bry a nt, Witness and Access. The Uses of the Fluid Text. „Textual Cultures” t. 2 (2007), nr 1 (Spring). Artykuł ten najlepiej chyba ze wszystkich prac Bryanta streszcza jego teorię tekstologiczną i związane $z$ nią problemy edytorskie.

31 Chodzi o pięcioletni (2020-2025) grant Narodowego Programu Rozwoju Humanistyki nr 0012/ NPRH8/H1 1/87/2019 realizowany w Instytucie Badań Literackich PAN. W ramach projektu przewidziano wydanie kilku tomów powieści Orzeszkowej jako początek dzieł zebranych - w klasycznej formie papierowej oraz w nowoczesnej edycji cyfrowej. 